\title{
THE EFFECTS OF CUSTOMER AND COMPETITOR ORIENTATIONS ON PERFORMANCE IN GLOBAL MARKETS: A CONTINGENCY ANALYSIS
}

Kevin Zheng Zhou ${ }^{1}$, James R Brown ${ }^{2}$, Chekitan S Dev ${ }^{3}$ and Sanjeev Agarwal ${ }^{4}$

July 25, 2006

\begin{abstract}
ACKNOWLEDGEMENTS
We thank Professor Krishna Erramilli, Jeff Weinstein of HOTELS magazine, and Vikram Mujumdar for their invaluable assistance in this research. We also thank the three anonymous JIBS reviewers and the Departmental Editor, Professor G Tomas M Hult, for their insightful and constructive comments.
\end{abstract}

\footnotetext{
${ }^{1}$ Correspondence author: KZ Zhou, Faculty of Business and Economics, School of Business, The University of Hong Kong, Meng Wah Complex, Pokfulam Road, Pokfulam, Hong Kong. Tel: 8522859 1011; Fax: 8522858 5614; E-mail: kevinzhou@business.hku.hk

2 JR Brown, College of Business and Economics, 1601 University Ave., West Virginia University, Morgantown, WV, 26506

${ }^{3}$ School of Hotel Administration, Cornell University, Statler Hall, Ithaca, NY, 14853

${ }^{4}$ College of Business, Iowa State University, 2167 Union Dr., Ames, IA, 50011
} 


\title{
THE EFFECTS OF CUSTOMER AND COMPETITOR ORIENTATIONS ON PERFORMANCE IN GLOBAL MARKETS: A CONTINGENCY ANALYSIS
}

\begin{abstract}
Should companies adjust their orientations toward customers or toward competitors in global markets? To answer this question, we use contingency theory and examine how the effects of customer and competitor orientations on performance are moderated by different environmental conditions. Our results from the global hotel industry indicate that a customer orientation works better in economically developed markets, as well as in markets with good local business conditions, greater resource availability, and demanding customers. In contrast, a competitor orientation is more effective in markets that are economically developing, have poor local business conditions, and face resource scarcity.
\end{abstract}

Keywords: customer orientation; competitor orientation; firm performance; market environment; hotel industry 


\section{INTRODUCTION}

Since the seminal works by Kohli and Jaworski (1990) and Narver and Slater (1990), marketing researchers have devoted much attention to the concept of market orientation and how it affects a firm's (or strategic business units) performance. A market orientation establishes the norms and beliefs that shape an integrated organizational effort to respond efficiently and effectively to customers and competitors. Thus market orientation is believed to have a positive effect on firm performance, as empirical research generally supports (e.g., Jaworski and Kohli, 1993; Han et al., 1998; Hult and Ketchen, 2001; Zhou et al., 2005).

Although a consensus seems to hold about the positive impact of market orientation, the literature provides different views about the roles of the two core components of market orientation: customer orientation and competitor orientation. Some researchers believe that these two components are conceptually of equal importance (Narver and Slater, 1990; Slater and Narver, 1994). Others argue that customer orientation may be the most fundamental aspect of market orientation (Peters and Austin, 1985; Deshpande' and Farley, 1998). Indeed, some assert that a competitor orientation can be antithetical to a customer orientation (Deshpande' et al., 1993), whereas others suggest that an effective strategic orientation requires a balanced mix of customer and competitor orientations (Day and Wensley, 1988; Gatignon and Xuereb, 1997; Voss and Voss, 2000).

Controversy also exists regarding the effectiveness of a market orientation in different environments. Because building one is costly and time-consuming, a market orientation is useful only if its benefits exceed the cost of the resources consumed. Kohli and Jaworski (1990) therefore posit that a market orientation may not be beneficial in situations with limited competition, stable market preferences, rapidly changing technology, and booming economies. Day and Wensley (1988) similarly suggest that the effects of market orientation are contingent on environmental factors (see also Gatignon and Xuereb, 1997; Voss and Voss, 2000). In contrast, Slater and Narver (1994) believe that market orientation is beneficial to performance regardless of the business condition. Slater and Narver (1998: 1005) explain that, because of its commitment to continuous learning, uncovering customer latent needs, and 
organization-wide integration of resources, a market orientation can enable a firm to 'achieve marketfocused innovation and to sustain competitive advantage in all types of markets' (italics added).

Another challenge within this literature is that, despite the growing interest in how market orientation shapes performance, the examination of its effects in global markets remains limited. Early empirical studies have been predominantly US-based (see Cadogan et al., 1999). Although a few studies recently have been conducted outside the US, they have focused on either a single market (e.g., China: Zhou et al., 2005) or a regional market (e.g., central Europe: Fahy et al., 2000). Moreover, only three articles on market orientation have appeared in Journal of International Business Studies thus far (Norburn et al., 1990; Cadogan et al., 1999; Fahy et al., 2000). Norburn et al. (1990) attempt to devise a measure of market orientation as a predictor of market effectiveness in four developed countries (UK, US, Australia, and New Zealand), but their scale does not possess sufficient reliability. Cadogan et al. (1999) successfully develop a scale of export market orientation and find it positively related to export performance in samples of UK and Dutch exporters; they encourage additional research to study the impact of environmental factors on the market orientation-performance relationship. Fahy et al. (2000) find that marketing capabilities such as market orientation led to better performance in central Europe. They also call for more examinations of market orientation in global markets and indicate that, to further our understanding of this issue, the role of macro-level environmental factors must be considered.

To address these research questions, we examine the role of customer and competitor orientations in global markets. Answering the call of Fahy et al. (2000), we test the effectiveness of customer and competitor orientations across markets facing different environments at the country (i.e., economic development), local market (i.e., local business conditions and resource availability), and consumer (i.e., customer demandingness) levels. In turn, our research context appears to provide an appropriate setting to test whether customer and competitor orientations behave similarly, and whether market orientation is beneficial in all types of markets. Overall, our research attempts to address inconsistencies in extant literature and provide insights for companies that want to adopt a customer- or competitor-oriented strategy to enhance their performance in global markets. 


\section{MARKET ORIENTATION}

As an aspect of corporate culture, a market orientation places the highest priority on creating and maintaining superior customer value profitably, and provides firm-wide norms and beliefs that guide organizational behaviors (Narver and Slater, 1990). It consists of three behavioral components: customer orientation, competitor orientation, and inter-functional coordination. To create superior customer value continuously, customer orientation emphasizes the role of sufficiently understanding target customers, competitor orientation focuses on understanding competitors' strengths and weaknesses and monitoring their activities, and inter-functional coordination emphasizes coordinating the use of company resources and customer-related activities throughout the entire organization (Narver and Slater, 1990).

Because each of these three components is critical for gathering, disseminating, and responding to market information (Kohli and Jaworski, 1990), Narver and Slater (1990) argue that they contribute equally to the construct of market orientation. However, others hold different opinions regarding the role of customer and competitor orientations. ${ }^{1}$ For example, some researchers suggest that customer orientation echoes the classic tenet of 'stay close to the customer' and 'put the customer at the top of the organizational chart' and therefore is the most essential part of a market orientation (Peters and Austin, 1985; Deshpande' and Farley, 1998). Others argue that a competitor orientation, with its focus on the strengths and weaknesses of its competitors rather than the particular needs of its customers, can be antithetical to a customer orientation (Deshpande' et al., 1993; Armstrong and Collopy, 1996).

Furthermore, Day and Wensley (1988) indicate that customer and competitor orientations are two distinct approaches that lead to competitive advantage. A customer orientation, with its detailed analyses of customer needs and wants, helps a firm satisfy its customers better, and thus is more likely to lead to a differentiation advantage. In contrast, a competitor orientation may lead to a cost advantage because competitor-oriented businesses tend to watch costs closely, so they may quickly match the marketing initiatives of competitors. Thus a customer/competitor orientation may be more/less effective in different situations, suggesting a contingency perspective of market orientation (see also Gatignon and Xuereb, 1997; Voss and Voss, 2000). 
Empirical support for the contingency view has been equivocal. For example, Jaworski and Kohli (1993) find that the effect of market orientation on performance is not significantly moderated by market turbulence, technological turbulence, or competitive intensity. Slater and Narver (1994) find only three of 12 conditions in which environmental factors significantly moderate the relative emphasis on the customer (vs competitor) orientation-performance relationship. On the basis of these findings, Slater and Narver (1994) conclude that, through its commitment to deliver superior customer value, a marketoriented business should be able to achieve and sustain competitive advantage in any environmental situation and, accordingly, managers should not attempt to match their market orientation to current market dynamics.

In contrast, Gatignon and Xuereb (1997) find in their cross-industry study that customer orientation is more effective when demand uncertainty increases; competitor orientation is less effective when demand uncertainty increases but works better when market growth is high. Han et al. (1998) find that, when technology changes rapidly, both customer and competitor orientations have a stronger impact on organizational innovations, which in turn improve firm performance; they posit that the significant or insignificant moderating findings may be due to industry differences.

Taken together, the empirical studies to date provide mixed results regarding the contingency view of market orientation. We suspect that these mixed findings show that the effects of customer and competitor orientations may be robust in relatively homogeneous contexts. However, because global markets are highly diversified in terms of economic development, consumption patterns, economic infrastructure, and so forth, a market orientation may play a different role in various international markets (Fahy et al., 2000). In other words, the diversity of global market environments may provide a stronger test of whether the effects of market orientation on performance depend on different environmental situations.

In this study, we use the global hotel industry as our context because its marketplace varies widely in terms of environmental factors such as economic development and local conditions. Taking contingency theory as our theoretical base, we examine the impact of customer and competitor 
orientations on performance across different levels of environments. Should we find no support for the moderating effects, we would concur with Slater and Narver $(1994,1998)$ that the effect of market orientation is truly robust across all business environments.

\section{HYPOTHESES}

According to contingency theory, the widely used perspective in understanding the strategyperformance relationship, there is no one best way to strategize, and no strategic choice is universally beneficial in all conditions (Lawrence and Lorsch, 1967; Ginsberg and Venkatraman, 1985; Donaldson, 2000). To achieve a competitive advantage, companies must match their strategic decisions to certain sets of contingency factors, including external (e.g., market conditions, buying behavior) and internal (e.g., organizational structures, characteristics, resources) environments (Lawrence and Lorsch, 1967; Donaldson, 2000). What intrigues strategy scholars most, and also addresses the heart of contingency theory, is how external environments moderate the strength of the strategy-performance relationship (Ginsberg and Venkatraman, 1985: 422).

Day and Wensley (1988) apply the logic of contingency theory to the market orientation context. They posit that, in conditions of predictable market demand, a stable and concentrated competitive structure, and a few powerful customers, the focus must be on competitors; in dynamic markets with highly segmented end-users, many competitors, and shifting entry barriers, an emphasis on a customer orientation is mandatory. Additional research has further developed the rationale for why the effects of customer and competitor orientations may be contingent on environmental factors such as market growth, buyer power, and competitive intensity (Jaworski and Kohli, 1993; Gatignon and Xuereb, 1997; Voss and Voss, 2000).

Central to contingency arguments, competitor orientation, through the direct comparison with target competitors, provides the firm with information about how it could reconfigure its value chain to achieve a cost advantage, whereas a customer orientation relies on intelligence from customers to devise strategies to achieve a differentiation advantage: therefore their effects are likely to be contingent on 
various environmental factors (Day and Wensley, 1988; Gatignon and Xuereb, 1997). Extending previous research, we examine the possible moderating roles of environmental factors such as the stage of economic development, local business conditions, resource availability, and customer demandingness. Although these factors might appear collinear, conceptually they reflect distinct aspects of global environments at the country, local market, and consumer levels, respectively. For example, economic development indicates a nation's overall stage of industrialization, whereas local business conditions and resource availability pertain more specially to the regional environments in areas where the hotels locate. Some areas in developed countries (e.g., tourist resorts) may suffer more from declining infrastructure (e.g., insufficient airport gates), resource shortages (e.g., lack of investment), etc. than some cities in less economically developed countries (e.g., Beijing, Shanghai) (Cateora and Graham, 2005). Customer demandingness represents a consumer- level dimension that may be independent of economic development. Some customers in developing countries may be more demanding than normally expected because of the cultural influence and consumption habits (Zhou et al., 2002).

\section{The effect of economic development}

The United Nations classifies a country's stage of economic development according to its level of industrialization (Cateora and Graham, 2005). Developed countries are those that are industrialized and have high per capita incomes (e.g., Canada, Japan, the UK, the US), whereas developing countries are those that are moving from an agrarian to an industrial economy and realize lower per capita incomes (e.g., Brazil, China, Indonesia).

People in developing markets have much less purchasing power than their counterparts in developed markets. For example, most households in North America and western Europe have annual purchasing capability of $\$ 20,000$ or more, whereas in the developing countries of South Asia, $75 \%$ of households have an annual purchasing power of less than \$5000 (Cateora and Graham, 2005). With such low incomes, customers in developing markets tend to be very price conscious, more concerned about the availability of products, and less sensitive to the variety of goods and services (Batra, 1997; Zhou et al., 
2002). In such conditions, offering a low-priced product to consumers is the primary success factor. To achieve this, a company must pay close attention to its competitors to benchmark its cost position on each aspect in the value chain. This competitor-oriented approach provides information for the company to reduce the cumulative cost of performing all the activities in its value chain to a level lower than the competitors' cost, and thereby achieve a cost advantage (Day and Wensley, 1988). That is, competitor orientation is a better way to serve consumers in developing countries.

As economies progress, consumers acquire more purchasing power and expanded tastes, leading to diverse market segments. Different consumers may desire special varieties of a product and be willing (and able) to pay a premium to get them rather than settle for a more standardized version (Porter, 1980). In markets with many segmented end-users, the firm's emphasis necessarily should shift toward discovering the unique needs of diversified customer segments, which provide companies with important customer intelligence about how to satisfy and exploit target segment opportunities (Day and Nedungadi, 1994). In addition, competition in developed markets intensifies as many companies enter the market. The increased number of competitors makes competitor monitoring more difficult and potentially less important (Slater and Narver, 1994). In this environment, focusing on the needs of customers and offering products especially tailored to them is more likely to lead to success.

Therefore we predict that:

H1a: The more developed the economy, the stronger the effect of customer orientation will be on performance.

H1b: The less developed the economy, the stronger the effect of competitor orientation will be on performance.

\section{The effects of business conditions}

The local market's business conditions, including the quality of the infrastructure, general business conditions, and political stability, also vary widely in global markets. The infrastructure (e.g., systems of communication, transportation, distribution) that some places take for granted can be 
problematic in other places. To handle this problem, companies may have to make necessary adjustments in their strategic orientations and operations. For example, an exporting company may be forced to establish its own sales subsidiary and distribution systems in a local market lack of reliable agents and distributors (Ekeledo and Sivakumar, 1998).

In poor business conditions, market-supporting institutions such as property rights-based legal systems, strategic factor markets, and stable political structures are lacking (Zhou et al., 2006). When formal, market-based supporting institutions are not available, companies must resort to informal, personal tie-based institutional support to secure their businesses (Peng and Heath, 1996). For example, closer ties with government officials (e.g., political leaders, officials in industry bureaus and regulatory and supporting organizations) help firms achieve more institutional support - such as interpreting regulations, enforcing contracts, settling negotiations, and erecting entry barriers - to counter threats and uncertainties (Peng and Luo, 2000; Li, 2005). Identifying with whom to network thus becomes of central importance for companies to coordinate their business transactions and foster organizational performance (Boisot and Child, 1996).

Monitoring competitors is an effective way to obtain such critical information. Using its rivals as a frame of reference, a firm can get to know the most significant and influential players it should approach, and then develop its own networking strategy to improve its institutional position and gain more institutional support. However, information from customers is less likely to generate insights that will help a firm build business networks, because most customer intelligence is remote from the activities inside the business (Day and Wensley, 1988). For example, fast order delivery involves the selection of shipping methods. In markets with poor business conditions, whether a firm can obtain reliable shipping service depends on its connection with a carrier. However, how to network with the carrier (e.g., with whom to get in touch) cannot be readily determined from information gleaned from customers. Instead, watching competitors closely enables the firm to understand how to develop its important business relationships. For these reasons, we predict that: 
H2a: The poorer the local business conditions, the weaker the effect of customer orientation will be on performance.

H2b: The poorer the local business conditions, the stronger the effect of competitor orientation will be on performance.

\section{The effects of resource availability}

In the global marketplace, the availability of important resources, such as qualified employees, managerial talent, reliable suppliers, and investors, differs greatly across markets. In some markets, skilled managers trained to compete in market-based economies are particularly lacking, as are the needed financial resources to fund growth (Peng and Heath, 1996). Because firms are constrained by and depend on others that control critical resources, they must actively seek ways to break down or alter the system of constraints and dependencies (Pfeffer and Salancik, 1978). Monitoring competitors represents one important way for a firm to achieve this objective. From information about its competitors, a firm can understand how others configure their value chains and secure scarce resources. Comparing their winning vs losing competitors further can illustrate what resources are key to success (Day and Wensley, 1988). Thus, by learning from the success and failure of its rivals, a competitor-oriented firm can better reconfigure its value chain to manage uncertainty, mitigate the influence of scarce resources, and achieve higher levels of performance.

However, when resources are scarce, monitoring customers may be less valuable. Although customer intelligence can reveal what customers desire, it offers little direction about how to secure necessary yet limited resources (Day and Wensley, 1988). In other words, even if a customer-oriented company knows what products to offer, it may lack the required personnel and managerial, supply, and financial resources to produce and deliver the products successfully. In such conditions, securing scarce resources is the primary means to survive and succeed (Peng and Heath, 1996). In contrast, in conditions in which resources are plentiful, customers dominate the market, and customer intelligence provides direct implications for firms to devise their strategies (Porter, 1980; Deshpande' et al., 1993). With few 
restrictions on resource availability, companies can put together all the needed resources and use them fully to create products attuned to customer requirements. Accordingly, being customer oriented is critical to success in these environments.

H3a: The higher the resource availability, the stronger the effect of customer orientation will be on performance.

H3b: The lower the resource availability, the stronger the effect of competitor orientation will be on performance.

\section{The effect of customer demandingness}

Customer demandingness refers to the extent to which customers require superior product or service performance (Li and Calantone, 1998). Demanding customers are more concerned about the benefits they receive from market offerings, better attuned to nuances and differences within a product category, and more attracted to products that are tailored specifically to their particular problems and needs. Because customers are very different in their perceptions of benefits, their demands or needs can be highly specific and heterogeneous (Monroe, 1990).

In such a market, a firm must develop a sufficient understanding of its target customers to deliver superior value to them (Day and Wensley, 1988). In addition, customers' perceptions of a product’s benefits may change over time; a firm's offering that matches the customers' needs today may not match their needs tomorrow ( $\mathrm{Li}$ and Calantone, 1998). Therefore a firm must continuously ascertain the changing preferences of its customers and adjust its offerings accordingly. In other words, when customers are demanding, the link between a customer orientation and performance will be stronger. In contrast, a competitor orientation may be less valuable when customers are highly demanding. Because competitor orientation emphasizes meeting and beating the competition, a competitor-oriented firm compares its capacities and offerings with those of its competitors (Day and Wensley, 1988). A potential caveat of this approach is that, after distinguishing between winning and losing competitors, managers tend to assume that the successful competitors are doing a proper marketing job, and are likely to emulate 
the competitors when devising strategies (Day and Wensley, 1988). In addition, by focusing on its competitors, a firm may be unaware of its real interest, which may lead to inconsistent strategies and behaviors and, consequently, unstable product offerings (Armstrong and Collopy, 1996). As a result, the firm may not be able to provide the products or services that are uniquely fitted to a particular market segment. Therefore we predict that:

H4a: The more demanding the customers, the stronger the effect of customer orientation will be on performance.

H4b: The more demanding the customers, the weaker the effect of competitor orientation will be on performance.

\section{METHODOLOGY}

\section{Sample}

To test our hypotheses, we selected the worldwide hotel industry as the empirical setting. Globally, the hotel industry is highly fragmented and characterized by a high failure rate. For example, in contrast with other product categories, the market share accounted for by the top three hotel brands amounts to only 15\% (MKG Consulting, 2002), and the survival rate for new hotel brands is slightly greater than 50\% (Coopers \& Lybrand, 1997). As a result, the industry is highly competitive, and companies increasingly turn to market orientation to achieve better performance (see also Brown and Dev, 2000).

Our unit of analysis is the individual hotel location. For the local environmental variables, we use perceptual measures that reflect the market conditions as perceived by each hotel's general manager. Because hotel general managers make decisions on the basis of their perceptions of local market conditions, we believe that the units of analysis are commensurate. Furthermore, our international sample offers enough variance in moderating variables such as local business conditions and customer demandingness to test our hypotheses. Thus our setting provides an appropriate context to assess whether the effects of market orientation on performance are contingent on environmental factors. 
The sampling frame was obtained from the Global Hoteliers Club, which publishes the global hotel industry’s leading trade journal, HOTELS (free for members). We sent 558 surveys to hotel general/senior managers who are Club members and asked them to report on their individual hotels. Our pretest revealed that these managers were knowledgeable about their individual hotels’ strategic orientations, performance, and surrounding environments. To increase the response rate, we included a cover letter from the CEO of the Global Hoteliers Club with the questionnaire. After two follow-up letters, we had received a total of 184 completed questionnaires. The response rate (32.9\%) is quite respectable compared with similar studies using international samples.

We checked for nonresponse bias in two ways. First, we compared early and late respondents on customer and competitor orientation, performance, and environmental variables and found no significant differences (Wilks' $. \wedge=0.968 ; F=0.426 ; P=0.959$ ), indicating an absence of nonresponse bias (Armstrong and Overton, 1977). Second, we conducted a follow-up survey of the nonrespondents in which we faxed a one-page survey containing 10 of the original questionnaire items to 38 nonrespondents (i.e., every 10th hotel of those who did not respond after the third letter). Eleven hotels (28.9\%) responded to the faxed questionnaire. A comparison showed that that they were statistically equivalent to the main sample respondents (Wilks’ $\Lambda=0.952 ; F=0.978 ; P=0.464$ ). Taking these results together, we concluded that nonresponse bias was negligible in our study.

Regarding the characteristics of the respondents, the managers may be expatriates or locals depending on each hotel's policy and practice. General managers of the local hotels represent $72.7 \%$ of the sample; the other $27.3 \%$ are senior managers. On average, they have been in their present positions for 6.7 years and in the hotel industry for 24.3 years, which suggests that they are rich in experience with hotel management and operations. In addition, most (72.3\%) respondents have a college or higher degree, indicating that they received similar educational programs from hotel schools. As Global Hoteliers Club members, they are generally fluent in English (the lingua franca of the hotel industry) and often speak multiple languages. Most have had standard hotel management training, and follow generally accepted industry practices for managing and marketing their hotels. As Dawar and Parker (1994) find in their 
cross-cultural study, these managers tend to have a similar answering pattern for survey questions. This comparative sample thus reduces concerns of measurement inequivalence.

On average, the hotels in the sample employed 433 people, offered 365 rooms for sale, and had been in operation for 22.9 years. In our sample, 53.7\% were independent and $46.3 \%$ belonged to 28 different hotel chains. On average, each chain owned 2.8 hotels in our sample. For those hotels that were part of a chain, their parent companies, on average, had engaged in international operations for 28.3 years, were affiliated with 328 hotels worldwide, and generated 58.2\% of their revenues from international properties. Finally, the hotels in our sample represented 56 countries (46.9\% in 26 OECD and 53.1\% in 30 non-OECD nations) across six continents; they thereby provide a variety of local markets.

\section{Measures}

After reviewing the relevant literature and conducting informal discussions with industry practitioners, we adapted most measures from previous work and developed some for this study. The questionnaire items were pretested on a sample of 30 international hotel general managers who attended an executive development program at a major US university. On the basis of their responses, we revised a few questionnaire items to enhance their clarity. The measurement items and results of the validity analyses appear in the Appendix.

Market orientation. We measured two dimensions of market orientation - customer orientation and competitor orientation - with five-point items (1: strongly disagree; 5: strongly agree) adapted from Narver and Slater (1990) to the hotel context. We also measured another dimension of market orientation - inter-functional coordination (also adapted from Narver and Slater, 1990) - and included it as a control variable. $^{2}$

Organizational performance. We adapted the measure of organizational performance from Moorman and Rust (1999). It asks the general managers to indicate their perceptions of their hotels' performance relative to their major competitors (1: much worse; 5: much better) in terms of occupancy, gross operating profit, and market share. We used a subjective measure of relative performance because: 
(1) such measures can control for variations in the performance caused by differences across market environments, whereas objective performance data may not be comparable across countries;

(2) previous studies have shown the convergent validity of subjective performance and their objective counterparts; and

(3) subjective assessments are often less problematic than more 'objective' financial measures, because the latter may be biased by the purpose for which they are produced (Gatignon and Xuereb, 1997).

Economic development. As we noted previously, the sample consists of 184 hotels from 56 countries, which vary according to their stage of economic development. Economically developed countries belong to the Organization for Economic Cooperation and Development (OECD), whereas less developed countries do not (see www.oecd.org). Therefore we coded OECD members as developed $(\mathrm{OECD}=1)$ and non-OECD members as developing (OECD-0) markets. Of our sample, $46.9 \%$ are from 26 OECD and $53.1 \%$ from 30 non-OECD countries. ${ }^{3}$

Local market environment. To assess the local market environment, we used 11 items designed especially for this study. An exploratory factor analysis collapsed these items into four factors: customer demandingness, local business conditions, resource availability, and availability of local investors. We found two factors for resource availability, one pertaining to human resources and reliable suppliers and the other to local investors (see the Appendix). Because both types of resources are important in the global market (Peng and Heath, 1996), we used both to test H3.

\section{Measurement invariance assessment}

Measurement invariance refers to whether measures of the same construct are consistent in different subgroups (e.g., cultures, countries) (Mullen, 1995). If a measure is variant, conclusions based on it are biased and misleading. To demonstrate measurement invariance, it is necessary to establish 
configural (the same pattern of factor loadings), metric (equal loadings), scalar (equal intercepts), factor variance, and error variance invariance for the measurement instruments (Steenkamp and Baumgartner, 1998).

With 184 respondents across 56 countries, we do not have a large enough sample size to test for measurement invariance across all the countries. Therefore we used a series of median splits to divide the whole sample into subgroups such as OECD vs non-OECD, poor vs good local business conditions, low vs high levels of resource availability, and demanding vs non-demanding customers. ${ }^{4}$ Then, following the multigroup comparison procedures proposed by Steenkamp and Baumgartner (1998), we assessed the measurement invariance for every construct measure across these subgroups. In the following, we illustrate this procedure with the test of customer orientation across the OECD and non-OECD groups (see Table 1a).

In the first step, we tested the equality of covariances of the six indicators of customer orientation across the OECD vs non-OECD groups. The test results $\left(x^{2}(21)=44.871, P=0.002\right.$; comparative fit index $(\mathrm{CFI})=0.944$, Tucker-Lewis index $(\mathrm{TLI})=0.920$; root mean square error of approximation $($ RMSEA $)=0.079$, and Akaike information criterion $($ AIC $)=86.871)$ provide an adequate fit to the data and suggest the invariance of the covariance matrices across the two groups.

We then turned to test the configural invariance: that is, to determine whether the indicators load on their respective factors in a similar pattern across groups. In this model, we allowed the scale indicators to load freely on the customer orientation factor in both the OECD and non-OECD groups. The results $\left(x^{2}(18)=35.363, P=0.009 ; C F I=0.959, T L I=0.932 ; R M S E A=0.073, A I C=83.363\right)$ indicate a good fit of the model. All factor loadings were highly significant in both groups $(\mathrm{P}<0.001)$, and the standardized factor loadings ranged between 0.51 and 0.85 . Therefore the measure of customer orientation appears to be configurally invariant across the OECD and non-OECD samples. This model was the baseline model with which we compared further restricted models.

The invariance tests of metric (constraining the matrix of factor loadings to be invariant), scalar (further imposing the intercepts of the factor loadings to be invariant), factor variance (further 
constraining factor variance to be equivalent), and error variance (further imposing error variance to be equivalent) all generated good fits to the data (see Table 1a). In addition, none of the chi-square difference tests comparing these models with the configural one were significant (see Table 1b, metric vs configural:

$\Delta x^{2}(5)=9.218, P=0.101 ;$ scalar $v s$ configural: $\Delta x^{2}(11)=11.809, P=$

0.378 ; factor varience $v s$ configural: $\Delta x^{2}(12)=12.163, P=$

0.433 ; error varience $v s$ configural: $\left.\Delta x^{2}(18)=25.395, P=0.114\right)$.

Taken together, these results suggest that the customer orientation scale is invariant across OECD and non-OECD groups.

Similarly, we tested the measurement invariance of customer orientation across subgroups of poor vs good business conditions, low vs high levels of resource availability, low vs high levels of investor availability, and low vs high levels of customer demandingness. All the results and chi-square difference tests suggest that the measure of customer orientation is configural, full metric, full scalar, factor variance, and full error variance invariant. Therefore the measure appears to be equivalent across global market conditions.

Following the same procedure, we tested the measurement invariance for competitor orientation, interfunctional coordination, performance, customer demandingness, local business conditions, and resource and investor availability. If the full invariance model was not adequate, we relaxed the constraints on certain indicators (as revealed by the modification index) to achieve an acceptable partial invariance model (see Steenkamp and Baumgartner, 1998: 84-87). The results (see Table 1b) indicate that the measures in our study survived the invariance tests: therefore the data could be pooled in subsequent analysis. ${ }^{5}$

Construct validity. We refined the measures and assessed their construct validity following the guidelines suggested by Anderson and Gerbing (1988). First, we ran exploratory factor analyses for each multi-item scale, which resulted in the theoretically expected factor solutions. Reliability analyses further 
showed that these measures possessed satisfactory reliability coefficients. Then, we estimated a ninefactor confirmatory factor analysis measurement model that included all our theoretical measures (see the Appendix). After we dropped an interfunctional coordination item that had an insufficiently large loading (i.e., $<0.50$ ), the model fitted the data satisfactorily: $x^{2}(290)=419.83, \mathrm{P}<0.001$; CFI $=0.93$, TLI $=$ 0.91; RMSEA $=0.049$; probability of close fit $=0.541$. Furthermore, all factor loadings were highly significant $(\mathrm{P}<0.001)$, the composite reliabilities of all constructs $(0.70-0.85)$ exceeded the usual 0.70 cutoff, and the average variance extracted indices were greater than or close to 0.50 benchmark (see the Appendix). Thus these measures demonstrate adequate convergent validity and reliability.

We assessed the discriminant validity of the measures in two ways. First, we ran pairwise, chisquare difference tests for all the scales (36 tests) to determine whether the restricted model (correlation fixed at 1.0) fitted the data significantly worse than the freely estimated model (correlation estimated freely). All chi-square differences were highly significant (e.g., the test for local business conditions and resource availability: $\left.\Delta x^{2}(1)=138.70, P=0.00\right)$, providing evidence of discriminant validity (Anderson and Gerbing, 1988). Second, we calculated the shared variance between all possible pairs of constructs to determine whether they were lower than the average variance extracted for the individual constructs. The results show that, for each construct, the average variance extracted was much higher than its highest shared variance with other constructs, in additional support of discriminant validity (see the Appendix) (Fornell and Larker, 1981). Overall, these results show that the measures in our study possess satisfactory reliability and validity.

Common method assessment. Because we collected information about most of the variables from the same respondent, common method bias may occur. We checked this potential problem with the test recommended by Cote and Buckley (1987). We estimated three models:

1. M1 was a method-only model in which all items were loaded on one factor $\left(x^{2}(325)=1830.15\right.$, $\mathrm{P}=0.000 ; \mathrm{CFI}=0.16, \mathrm{TLI}=0.09 ; \mathrm{RMSEA}=0.159)$. 
2. M2 was a trait-only model in which each item was loaded on its respective scale $\left(x^{2}(290)=\right.$ 419.83, $\mathrm{P}<0.001 ; \mathrm{CFI}=0.93, \mathrm{TLI}=0.91 ; \mathrm{RMSEA}=0.049$ ).

3. M3 was a trait and method model in which a common factor linking to all the measurement items was added into M2 $\left(x^{2}(264)=341.06, \mathrm{P}<0.001 ; \mathrm{CFI}=0.96, \mathrm{TLI}=0.94 ; \mathrm{RMSEA}=0.040\right)$.

Comparing these three models, M3 and M2 demonstrate a much better fit than M1 to the data, and the fit of M3 is only slightly better than that of M2. This shows that the trait rather than the common method factor explains most of the variance. Because the common factor does not sufficiently describe the data, common method bias is unlikely to be a concern for our study.

Controls. To account for extraneous variables that might influence a firm’s performance, we included economic growth, government restrictions, entry barriers, competitive intensity, firm size, and innovation orientation as control variables. A fast-growing economy may enable a firm to achieve better performance (Narver and Slater, 1990). We calculated economic growth as the average GDP growth rate in the three years prior to the survey, using information obtained from The World Economic Factbook by Euromonitor. In addition, in the global market, finely tuned government regulations are critical for firms to operate efficiently (Peng and Heath, 1996), so we measured it with a five-point item that assessed the impact of government regulations on hotel operations $(1=$ very poor; $5=$ very good $)$. To reflect the importance of location in the hotel industry, we measured a firm's possession of entry barriers according to responses to the item: 'We pre-empt our competitors by building our properties in prime locations. Once taken, they are left with only inferior locations' ( 1 = strongly disagree; 5 = strongly agree). Competitive intensity also may affect firm performance significantly ( $\mathrm{Li}$ and Calantone, 1998); we assessed it by the extent of aggressiveness of competitors ( $1=$ very low; $5=$ very high). We measured firm size as the logarithm of the number of rooms the hotel offers. Larger organizations may have access to scarce resources that enable them to generate superior performance (Narver and Slater, 1990). Finally, an innovation orientation drives organizational performance (e.g., Hurley and Hult, 1998; Hult and Ketchen, 2001). We measured it with the following item: 'We are constantly investing in generating new 
capabilities that give us an advantage compared with our competitors' ( 1 = strongly disagree; 5 = strongly agree).

In Table 2, we present the means, standard deviations, and correlations for all the construct measures.

\begin{abstract}
ANALYSIS
Because our hypotheses suggest interaction terms composed of market orientation and environmental factors, a moderated regression analysis is appropriate for testing these effects (Jaccard et al., 1990). To deal with possible multicollinearity between the interactions terms and their components, we mean-centered each scale that constitutes an interaction term and then created the interaction terms by multiplying the relevant mean-centered scales (Jaccard et al., 1990). Furthermore, because correlations among interaction terms containing the same components are likely to produce multicollinearity, we employed a block-wise hierarchical approach to test our hypotheses (cf. Elvira and Cohen, 2001: 599; McGrath, 2001: 125). This block-wise procedure resulted in seven models, labeled M1-M7 (Table 3). In these seven models, the largest variance inflation factor, a multicollinearity indicator, is 2.22 , which is well below the usual 10.0 benchmark (Hair et al., 1998). Thus multicollinearity is not a concern here.
\end{abstract}

\title{
RESULTS
}

As we show in Table 3, for models M2-M7 the main effect of a customer orientation on performance is positive and significant, but the main effects of a competitor orientation and interfunctional coordination on performance are not significant in any model. These results are consistent with the observation that a customer orientation is more important in service-intensive industries (e.g., the hotel industry) (Day and Nedungadi, 1994).

As shown in Table 3, in M3 the customer orientation x OECD interaction is positive and significant $(0.29, \mathrm{P}<0.01)$, which indicates that customer orientation has a stronger effect in developed markets. In contrast, the competitor orientation x OECD interaction is negative and significant $(-0.29, \mathrm{P}<$ 
0.01), thereby signifying that competitor orientation has a stronger performance impact in developing markets, and supporting H1.

The results for M4 show that customer orientation is more effective $(0.19, \mathrm{P}<0.01)$ and competitor orientation is less effective $(-0.12, \mathrm{P}<0.10)$ when local business conditions are more favorable, in support of $\mathrm{H} 2$.

M5 and M6 assess the moderating roles of resource and investor availability (H3). The results show that when resources and investors are both widely available, a customer orientation leads to stronger firm performance ( $0.12, \mathrm{P}<0.10 ; 0.15, \mathrm{P}<0.05$, respectively), whereas a competitor orientation is less fruitful (-0.17, $\mathrm{P}<0.01 ;-0.28, \mathrm{P}<0.01$, respectively). Stated differently, a competitor orientation is more effective and a customer orientation is less productive when resources become scarce. These results support H3.

Consistent with H4a, the interaction between customer orientation and customer demandingness is positive and significant $(0.16, \mathrm{P}<0.05$; see M7). However, contrary to our expectations in $\mathrm{H} 4 \mathrm{~b}$, the interaction between competitor orientation and customer demandingness is not significant (-0.05, P > 0.10). Thus our results provide mixed support for H4.

To understand the interaction effects better, we also employed subgroup analysis to examine the effects of market orientation across low vs high levels of environmental variables. Following the procedure by Jaccard et al. (1990: 46), we conducted additional analyses to determine whether the coefficient differences are statistically significant; we present the parameter estimates that pertain to our hypothesis testing in Table 4.

Highly consistent with the results of Table 3, Table 4 shows that a customer orientation bolsters performance in developed markets and in markets with better local business conditions, higher levels of resource availability, and highly demanding customers. However, it has no significant impact on performance in developing markets or those with poor local business conditions, lower levels of resource availability, and less demanding customers. The opposite is true for a competitor orientation, except with 
regard to less demanding customers, in which case competitor orientation has no significant effect on performance. Therefore our hypotheses are supported except for H4b.

Moreover, Table 4 shows that a competitor orientation may have a negative impact on performance in contexts with high levels of investor availability. Investors may be attracted to markets that have other available resources as well as favorable governmental regulations and local business conditions (see Table 2). In the hotel industry, this typically means investors lining up to buy hotels, expand existing hotels, or build new ones. In such markets, information generated from competitor monitoring on how to secure scarce resources and how to network to gain institutional support becomes less beneficial for business success. As a result, the benefits gained from competitor orientation may even outweigh the costs involved, as competitor monitoring is not an easy task and can absorb many resources (Jaworski and Kohli, 1993). Therefore a competitor orientation may lead to declining performance in such conditions.

The effects of controls. As Table 3 shows, economic growth is positively related to performance, suggesting that firms can achieve better performance in faster-growing markets. Well-developed government regulations help enable companies to perform better, as do entry barriers erected by a firm. In addition, neither competitive intensity nor firm size has a significant impact on performance. Finally, an innovation orientation strengthens firm performance.

\section{DISCUSSION}

While market orientation has generated substantial attention in both theoretical and empirical studies, the literature provides inconsistent evidence about the roles of customer and competitor orientation and how environmental factors affect those roles. Our study seeks to clarify such inconsistencies by examining the effects of customer/competitor orientation across various market environments. Our study contributes to the literature in the following ways.

First, our study advances the market orientation literature by identifying whether and how customer and competitor orientations affect performance differently. Contrary to the assertion that 
businesses should not adjust their customer or competitor orientations to match market conditions (e.g., Slater and Narver, 1994, 1998), our results show that customer and competitor orientations behave differently and that their performance impacts vary across different market conditions. These findings are consistent with contingency arguments that companies should match their customer and competitor orientations to different environments (Day and Wensley, 1988; Gatignon and Xuereb, 1997; Voss and Voss, 2000). As such, our findings shed some light on the contradictions that appear in the literature.

Furthermore, our study enriches understanding of the contingency view of market orientation by examining the boundary conditions for customer and competitor orientations, a research void deserving more examination (Hult and Ketchen, 2001; Zhou et al., 2005). In particular, we find that, at the country level, customer orientation works better in developed countries whereas competitor orientation is more effective in developing countries. At the local market level, customer orientation is more valuable in more munificent markets that have favorable business conditions and possess readily available resources. In contrast, competitor orientation seems more helpful in leaner markets with poorer local business conditions and lower levels of resource availability. At the consumer level, demanding customers are better served by following a customer orientation. The findings also suggest that competitor information is qualitatively different from customer intelligence; the former seems more helpful to a firm that wants to reconfigure its value chain and secure scarce resources to achieve a cost advantage, whereas the latter enables a firm to understand customer needs better and obtain a differentiation advantage. Thus a customer orientation is more appropriate in rich environments, and a competitor orientation is more effective in lean market conditions.

Time and again, scholars have noted the need to study market orientation in non-US and international contexts (Kohli and Jaworski, 1990; Cadogan et al., 1999; Fahy et al., 2000; Zhou et al., 2005). With an international sample consisting of respondents from 56 countries on six continents, our study is the first to examine the effects of market orientation in a global context. Our examination of how environmental factors around the globe moderate the market orientation-performance relationship also deepens our understanding of the role of market orientation in international markets. 
Methodologically, studies in the international arena have long been criticized as lacking the validity of measurement invariance (e.g., Mullen, 1995; Steenkamp and Baumgartner, 1998). In this respect, our efforts to establish measurement invariance contribute to international business research. In line with previous researchers' recommendations, our study assesses and verifies the invariance of our focal construct measures across a series of subgroups of market conditions, including stage of economic development, local business conditions, resource and investor availability, and customer demandingness. Thus our approach represents an alternative way to address the problem of measurement invariance in studies of international business.

\section{Managerial implications}

Our findings have direct implications for how firms should match their customer or competitor orientation with the nature of the market in which they operate. At the country level, following a customer orientation seems more advantageous for firms that operate in developed markets, in that it significantly enhances organizational performance, but it has no effect on performance in developing markets. Instead, firms in developing markets should pursue a competitor orientation to improve their performance.

At the local market level, in markets in which business conditions are good and resources are readily available, a customer-oriented strategy will enable firms to achieve superior performance. In contrast, when the markets suffer poor business conditions or face limited resources, being competitor oriented will more likely lead to success. In the latter condition, a company should use information from its competitors to learn how to obtain institutional support and secure scarce resources to enhance its performance.

Furthermore, when customers are highly demanding, a customer orientation boosts performance by stimulating the firm to understand their particular needs and provide market offerings that satisfy those needs. However, a competitor orientation has little impact on performance, regardless of how demanding the firm's customers are. This finding suggests that firms should explore various customer-centric approaches to achieve better performance for demanding customers. 


\section{Limitations and further research}

As with any study, ours has some limitations that point to directions for further research. First, our research context is the hotel industry. As a customer orientation may be particularly important in service industries, samples from other industries such as the manufacturing sector are needed to generalize our findings and further assess the boundary conditions for customer and competitor orientations. Second, our performance measures are based on managers’ perceptions. Although previous research has demonstrated the acceptability of perceptual performance measures (e.g., Gatignon and Xuereb, 1997), social desirability may be a concern for such perceptual performance measure (the mean is 3.79 out of 5.00; see Table 2). Archival performance measures such as financial reports, customer satisfaction tracking studies, and industry analysts' reports would be helpful to validate the model. Third, we focus specifically on customer and competitor orientations, though many successful firms may have followed a selling, learning, or entrepreneurial orientation (Voss and Voss, 2000; Hult and Ketchen, 2001; Noble et al., 2002; Zhou et al., 2005). Additional research is encouraged to test the contributions of other orientations to organizational performance in the global marketplace. 


\section{NOTES}

1. Researchers seem to agree that the coordinated use of resources (i.e., interfunctional coordination) is critical for a firm to deliver superior customer value (e.g., Kohli and Jaworski, 1990; Narver and Slater, 1990; Deshpande et al., 1993). Therefore we focus on the customer and competitor orientation facets of market orientation and assess their effectiveness across different environments.

2. We assessed the validity of market orientation as a second-order construct with three first-order factors. (i.e., customer orientation, competitor orientation, and interfunctional coordination). The confirmatory model fitted the data satisfactorily $\left(x^{2}(51)=79.589, P=0.006\right.$; confirmatory fit index $(\mathrm{CFI})=0.962$, Tucker-Lewis index $(\mathrm{TLI})=0.951$; root mean square error of approximation $($ RMSEA $)=0.055)$, and the composite reliability of market orientation is 0.746 , which suggests that market orientation as a second-order factor possesses adequate validity.

3. In the sample, OECD markets include Australia, Austria, Belgium, Canada, the Czech Republic, Denmark, Finland, France, Germany, Greece, Ireland, Italy, Japan, Mexico, the Netherlands, New Zealand, Poland, Portugal, Singapore, South Korea, Spain, Sweden, Switzerland, Turkey, the United Kingdom, and the United States. Non-OECD markets include Aruba, Azerbaijan, Bahrain, Benin, Botswana, Brazil, Cambodia, China, Egypt, India, Indonesia, Kenya, Malaysia, Mauritius, Morocco, Myanmar, Oman, Pakistan, Peru, the Philippines, Saudi Arabia, Senegal, South Africa, Sri Lanka, Thailand, Uganda, Vietnam, West Africa, the West Indies, and Zaire.

4. We thank an anonymous reviewer for suggesting this approach.

5. Because of space constraints, we report only the invariance test results across OECD vs non-OECD groups in Table 1b. Additional results are available on request. 


\section{REFERENCES}

Anderson, J.C. and Gerbing, D.W. (1988) ‘Structural equation modeling in practice: a review of recommended two-step approach’, Psychological Bulletin 103(3): 411-423.

Armstrong, J.S. and Collopy, F. (1996) 'Competitor orientation: effects of objectives and information on managerial decisions and profitability’, Journal of Marketing Research 33(2): 188-199.

Armstrong, J.S. and Overton, T.S. (1977) ‘Estimating nonresponse bias in mail surveys’, Journal of Marketing Research 14(3): 396-402.

Batra, R. (1997) 'Marketing issues and challenges in transitional economics’, Journal of International Marketing 5(4): 95-114.

Boisot, M. and Child, J. (1996) 'From fiefs to clans and network capitalism: explaining China’s emerging economic order’, Administrative Science Quarterly 41(4): 600-628.

Brown, J.R. and Dev, C.S. (2000) 'Improving productivity in a service business: evidence from the hotel industry', Journal of Service Research 2(2): 339-354.

Cadogan, J.W., Diamantopoulos, A. and Mortanges, C.P. (1999) ‘A measure of export market orientation: scale development and cross-cultural validation', Journal of International Business Studies 30(4): 689707.

Cateora, P.R. and Graham, J.L. (2005) International Marketing, 12th edn, McGraw-Hill Companies: New York.

Coopers \& Lybrand (1997) 'Product differentiation and innovation in a maturing lodging industry: a review of brand introductions in the 1980 to 1996 period', Coopers \& Lybrand Hospitality Direction (February).

Cote, J.A. and Buckley, M.R. (1987) 'Estimating trait, method, and error variance: generalizing across 70 construct validation studies', Journal of Marketing Research 24(3): 315-318. 
Dawar, N. and Parker, P. (1994) 'Marketing universals: consumers’ use of brand name, price, physical appearance, and retailer reputation as signals of product quality', Journal of Marketing 58(2): 81-95.

Day, G.S. and Nedungadi, P. (1994) 'Managerial representations of competitive advantage’, Journal of Marketing 58(2): 31-44.

Day, G.S. and Wensley, R. (1988) ‘Assessing advantage: a framework for diagnosing competitive superiority', Journal of Marketing 52(2): 1-20.

Deshpande', R. and Farley, J.U. (1998) 'Measuring market orientation: generalization and synthesis', Journal of Market-Focused Management 2(3): 213-232.

Deshpande’, R., Farley, J.U. and Webster Jr, F. (1993) ‘Corporate culture, customer orientation, and innovativeness in Japanese firms: a quadrad analysis’, Journal of Marketing 57(1): 23-37.

Donaldson, L. (2000) The Contingency Theory of Organizations, Sage: Thousand Oaks, CA.

Ekeledo, I. and Sivakumar, K. (1998) 'Foreign market entry mode choice of service firms: a contingency perspective', Journal of the Academy of Marketing Science 26(4): 274-292.

Elvira, M.M. and Cohen, L.E. (2001) 'Location matters: a cross-level analysis of the effects of organizational sex composition on turnover', Academy of Management Journal 44(3): 591-605.

Fahy, J., Hooley, G., Cox, T., Beracs, R., Fonfara, K. and Snoj, B. (2000) 'The development and impact of marketing capabilities in Central Europe', Journal of International Business Studies 31(1): 63-81.

Fornell, C. and Larker, D.F. (1981) ‘Evaluating structural equation models with unobservable variables and measurement error’, Journal of Marketing Research 18(1): 39-50.

Gatignon, H. and Xuereb, J. (1997) ‘Strategic orientation of the firm and new product performance’, Journal of Marketing Research 34(1): 77-90.

Ginsberg, A. and Venkatraman, N. (1985) 'Contingency perspectives of organizational strategy: a critical review of the empirical research', Academy of Management Review 10(3): 421-434. 
Hair, J.F., Anderson, R.E., Tatham, R.L. and Black, W.C. (1998) Multivariate Data Analysis, PrenticeHall: Upper Saddle River, New Jersey.

Han, J.K., Kim, N. and Srivastava, R.K. (1998) 'Market orientation and organizational performance: is innovation a missing link?’ Journal of Marketing 62(4): 30-45.

Hult, G.T.M. and Ketchen Jr, D.J. (2001) 'Does market orientation matter? A test of the relationship between positional advantage and performance’, Strategic Management Journal 22(9): 899-906.

Hurley, R.F. and Hult, G.T.M. (1998) ‘Innovation, market orientation, and organizational learning: an integration and empirical examination', Journal of Marketing 62(3): 42-54.

Jaccard, J., Turrisi, R. and Wan, C.K. (1990) Interaction Effects in Multiple Regression, Sage: Newbury Park, CA.

Jaworski, B.J. and Kohli, A.K. (1993) ‘Market orientation: antecedents and consequences’, Journal of Marketing 57(3): 53-70.

Kohli, A.K. and Jaworski, B.J. (1990) 'Market orientation: the construct, research propositions, and managerial implications', Journal of Marketing 54(2): 1-18.

Lawrence, P.R. and Lorsch, J.W. (1967) Organization and Environment: Managing Differentiation and Integration, Harvard Business School Press: Boston, MA.

Li, J.J. (2005) 'The formation of managerial networks of foreign firms in China: the effects of strategic orientations', Asia Pacific Journal of Management 22(4): 423-443.

Li, T. and Calantone, R.J. (1998) 'The impact of market knowledge competence on new product advantage: conceptualization and empirical examination’, Journal of Marketing 62(4): 13-29.

McGrath, R.G. (2001) 'Exploratory learning, innovative capacity, and managerial oversight', Academy of Management Journal 44(1): 118-131.

MKG Consulting (2002) ‘Worldwide ranking of hotel groups’, www.mkgconseil.com. 
Monroe, K.B. (1990) Pricing: Making Profitable Decisions, McGraw-Hill: New York.

Moorman, C. and Rust, R.T. (1999) ‘The role of marketing', Journal of Marketing 63(Special Issue): 180-197.

Mullen, M.R. (1995) ‘Diagnosing measurement equivalence in cross-national research', Journal of International Business Studies 26(3): 573-596.

Narver, J.C. and Slater, S.F. (1990) 'The effect of a market orientation on business profitability', Journal of Marketing 54(4): 20-35.

Noble, C.H., Sinha, R.K. and Kumar, A. (2002) 'Market orientation and alternative strategic orientations: a longitudinal assessment of performance implications', Journal of Marketing 66(October): 25-39.

Norburn, D., Birley, S., Dunn, M. and Payne, A. (1990) ‘A four nation study of the relationship between marketing effectiveness, corporate culture, corporate values, and market orientation', Journal of International Business Studies 21(3): 451-468.

Peng, M.W. and Heath, P.S. (1996) 'The growth of the firm in planned economies in transition: institutions, organizations, and strategic choice’, Academy of Management Review 21(2): 492-528.

Peng, M.W. and Luo, Y. (2000) 'Managerial ties and firm performance in a transition economy: the nature of a micro-macro link', Academy of Management Journal 43(3): 486-501.

Peters, T.J. and Austin, N. (1985) A Passion for Excellence, Random House: New York.

Pfeffer, J. and Salancik, C.R. (1978) The External Control of Organizations: A Resource Dependence Perspective, Harper \& Row: New York.

Porter, M. (1980) Competitive Strategy, The Free Press: New York.

Slater, S.F. and Narver, J.C. (1994) 'Does competitive environment moderate the market orientationperformance relationship?’ Journal of Marketing 58(1): 46-55. 
Slater, S.F. and Narver, J.C. (1998) ‘Customer-led and market-oriented: let’s not confuse the two’, Strategic Management Journal 19(10): 1001-1006.

Steenkamp, J.E.M. and Baumgartner, H. (1998) ‘Assessing measurement invariance in cross-national consumer research', Journal of Consumer Research 25(1): 78-90.

Voss, G.B. and Voss, Z.G. (2000) 'Strategic orientation and firm performance in an artistic environment', Journal of Marketing 64(1): 67-83.

Zhou, K.Z., Su, C. and Bao, Y. (2002) 'A paradox of price-quality and market efficiency: a comparative study of the US and China markets', International Journal of Research in Marketing 19(4): 349-365.

Zhou, K.Z., Tse, D.K. and Li, J.J. (2006) 'Organizational change in emerging economies: drivers and consequences', Journal of International Business Studies 37(2): 248-263.

Zhou, K.Z., Yim, C.K. and Tse, D.K. (2005) 'The effects of strategic orientations on technology- and market-based breakthrough innovations', Journal of Marketing 69(2): 42-60. 
Table 1. Measurement invariance assessment.

(a) An example of test procedure: customer orientation across OECD and non-OECD groups

\begin{tabular}{lccccccc}
\hline Model & $\chi^{2}$ & d.f. & P-value & CFI & TLI & RMSEA & AIC \\
\hline Equality of covariances & 44.871 & 21 & 0.002 & 0.944 & 0.920 & 0.079 & 86.871 \\
Configural invariance & 35.363 & 18 & 0.009 & 0.959 & 0.932 & 0.073 & 83.363 \\
Metric invariance & 44.581 & 23 & 0.004 & 0.949 & 0.934 & 0.072 & 82.581 \\
Scalar invariance & 47.172 & 29 & 0.018 & 0.950 & 0.938 & 0.059 & 82.596 \\
Factor variance invariance & 47.526 & 30 & 0.022 & 0.951 & 0.938 & 0.069 & 80.950 \\
Error variance invariance & 60.758 & 36 & 0.006 & 0.933 & 0.933 & 0.072 & 82.194 \\
& & & & & & &
\end{tabular}

(b) Test results of major constructs across OECD vs non-OECD groups

\begin{tabular}{|c|c|c|c|c|c|}
\hline \multirow[b]{2}{*}{ Construct } & \multirow[b]{2}{*}{$\begin{array}{l}\text { Relaxed } \\
\text { item }^{\mathrm{a}}\end{array}$} & \multicolumn{4}{|c|}{$\Delta \chi^{2}$ test } \\
\hline & & $\begin{array}{l}\text { Metric vs } \\
\text { configural }\end{array}$ & $\begin{array}{l}\text { Scalar vs } \\
\text { configural }\end{array}$ & $\begin{array}{l}\text { Factor variance } \\
\text { vs configural }\end{array}$ & $\begin{array}{l}\text { Error variance vs } \\
\text { configural }\end{array}$ \\
\hline Customer orientation & - & $\begin{array}{l}\Delta \chi^{2}(5)=9.218, \\
P=0.101\end{array}$ & $\begin{array}{l}\Delta \chi^{2}(11)=11.809, \\
P=0.378\end{array}$ & $\begin{array}{l}\Delta \chi^{2}(12)=12.163, \\
P=0.433\end{array}$ & $\begin{array}{l}\Delta \chi^{2}(18)=25.395, \\
P-0.114\end{array}$ \\
\hline Competitor orientation & Item 3 & $\begin{array}{l}\Delta \chi^{2}(1)=2.036, \\
P=0.154\end{array}$ & $\begin{array}{l}\Delta \chi^{2}(4)=5.020 \\
P=0.285\end{array}$ & $\begin{array}{l}\Delta \chi^{2}(5)=6.684, \\
P=0.245\end{array}$ & $\begin{array}{l}\Delta \chi^{2}(8)=9.586 \\
P=0.135\end{array}$ \\
\hline Interfunctional coordination & - & $\begin{array}{l}\Delta \chi^{2}(2)=0.005, \\
P=0.998\end{array}$ & $\begin{array}{l}\Delta \chi^{2}(5)=6.829 \\
P=0.234\end{array}$ & $\begin{array}{l}\Delta \chi^{2}(6)=7.294 \\
P=0.294\end{array}$ & $\begin{array}{l}\Delta \chi^{2}(9)=13.198, \\
P=0.154\end{array}$ \\
\hline Performance & Item 2 & $\begin{array}{l}\Delta \chi^{2}(1)=2.415, \\
P=0.165\end{array}$ & $\begin{array}{l}\Delta \chi^{2}(4)=3.917 \\
P=0.417\end{array}$ & $\begin{array}{l}\Delta \chi^{2}(5)=4.708, \\
P=0.453\end{array}$ & $\begin{array}{l}\Delta \chi^{2}(8)=11.060 \\
P=0.198\end{array}$ \\
\hline Customer demandingness & - & $\begin{array}{l}\Delta \chi^{2}(2)=0.052, \\
P=0.974\end{array}$ & $\begin{array}{l}\Delta \chi^{2}(5)=0.429 \\
P=0.995\end{array}$ & $\begin{array}{l}\Delta \chi^{2}(6)=2.955, \\
P=0.814\end{array}$ & $\begin{array}{l}\Delta \chi^{2}(9)=5.927 \\
P=0.747\end{array}$ \\
\hline Local business conditions & - & $\begin{array}{l}\Delta \chi^{2}(2)=0.969, \\
P=0.616\end{array}$ & $\begin{array}{l}\Delta \chi^{2}(5)=6.563 \\
P=0.261\end{array}$ & $\begin{array}{l}\Delta \chi^{2}(6)=7.645, \\
P=0.165\end{array}$ & $\begin{array}{l}\Delta \chi^{2}(9)=14.163, \\
P=0.137\end{array}$ \\
\hline Resource $^{b}$ availability & Item 3 & $\begin{array}{l}\Delta \chi^{2}(2)=0.382 \\
P=0.826\end{array}$ & $\begin{array}{l}\Delta \chi^{2}(6)=7.341, \\
P=0.287\end{array}$ & $\begin{array}{l}\Delta \chi^{2}(8)=9.693 \\
P=0.132\end{array}$ & $\begin{array}{l}\Delta \chi^{2}(12)=15.747, \\
P=0.241\end{array}$ \\
\hline Investor $^{\mathrm{b}}$ availability & - & & & & \\
\hline
\end{tabular}

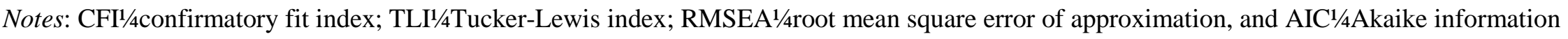
criterion.

${ }^{a}$ Relaxed item refers to the item that is not equivalent in their loadings across the groups. Please see the Appendix for details on the scale items.

${ }^{\mathrm{b}}$ The assessment of resource and investor availability was run in the same model because investor availability has only two measurement items. 
Table 2. Basic descriptive statistics of the constructs.

\begin{tabular}{|c|c|c|c|c|c|c|c|c|c|c|c|c|c|c|c|c|}
\hline Construct & & 1 & 2 & 3 & 4 & 5 & 6 & 7 & 8 & 9 & 10 & 11 & 12 & 13 & 14 & 15 \\
\hline 1. & Performance & 1.00 & & & & & & & & & & & & & & \\
\hline 2. & Customer orientation & $0.21 * *$ & 1.00 & & & & & & & & & & & & & \\
\hline 3. & Competitor orientation & 0.13 & $0.33^{* *}$ & 1.00 & & & & & & & & & & & & \\
\hline 4. & Interfunctional coordination & 0.00 & $0.43^{* *}$ & $0.37^{* *}$ & 1.00 & & & & & & & & & & & \\
\hline 5. & OECD & 0.02 & 0.09 & 0.00 & $0.19^{* *}$ & 1.00 & & & & & & & & & & \\
\hline 6. & Local business condition & -0.06 & 0.07 & 0.05 & $0.24^{* *}$ & $0.34^{* *}$ & 1.00 & & & & & & & & & \\
\hline 7. & Resource availability & 0.00 & -0.05 & 0.14 & $0.21^{\text {\#* }}$ & $0.42^{* *}$ & $0.47^{* *}$ & 1.00 & & & & & & & & \\
\hline 8. & Investor availability & 0.11 & 0.04 & 0.11 & 0.07 & 0.03 & $0.25^{* *}$ & $0.36^{* *}$ & 1.00 & & & & & & & \\
\hline 9. & Customer demandingness & 0.03 & $0.28^{* *}$ & $0.25^{* *}$ & $0.30^{* *}$ & 0.02 & 0.10 & 0.09 & 0.03 & 1.00 & & & & & & \\
\hline 10. & Economic growth & $0.18^{*}$ & 0.06 & 0.05 & 0.00 & 0.13 & 0.01 & 0.02 & $0.20^{* *}$ & 0.02 & 1.00 & & & & & \\
\hline 11. & Government regulation & 0.14 & -0.08 & 0.05 & 0.06 & $0.21 *$ & $0.31^{* *}$ & $0.29^{* *}$ & $0.15^{*}$ & -0.01 & 0.10 & 1.00 & & & & \\
\hline 12. & Entry barrier & $0.27^{* *}$ & $0.21 *$ & $0.20^{* *}$ & 0.10 & -0.01 & 0.06 & 0.08 & $0.19^{* *}$ & $0.17^{*}$ & 0.05 & 0.06 & 1.00 & & & \\
\hline 13. & Competitive intensity & -0.09 & -0.03 & 0.11 & $0.15^{*}$ & -0.10 & $0.15^{*}$ & $0.18^{*}$ & 0.07 & 0.03 & -0.13 & -0.05 & -0.01 & 1.00 & & \\
\hline 14. & Firm size & 0.02 & -0.04 & 0.04 & $-0.22^{* *}$ & $-0.20^{* *}$ & $-0.18^{*}$ & -0.08 & 0.07 & $-0.27^{* *}$ & 0.10 & -0.09 & 0.02 & $0.16^{*}$ & 1.00 & \\
\hline \multirow[t]{3}{*}{15.} & Innovation orientation & $0.25^{* *}$ & $0.49^{* *}$ & $0.28^{* *}$ & $0.38^{* *}$ & $0.15^{\star}$ & 0.09 & 0.06 & -0.01 & $0.26^{* *}$ & 0.12 & 0.13 & 0.22 & -0.02 & $-0.15^{*}$ & 1.00 \\
\hline & Mean & 3.79 & 4.13 & 4.04 & 3.88 & 0.47 & 3.66 & 2.83 & 2.72 & 3.82 & 3.47 & 3.38 & 2.76 & 3.82 & 5.75 & 3.65 \\
\hline & Standard deviation & 0.72 & 0.59 & 0.61 & 0.67 & 0.50 & 0.99 & 0.93 & 0.94 & 0.70 & 2.78 & 1.17 & 0.97 & 0.90 & 0.58 & 0.94 \\
\hline
\end{tabular}

Notes: $N=184$.

${ }^{* *} P<0.01, * P<$ (two-tailed). 
Table 3. Standardized estimates: multiple moderated regressions.

\begin{tabular}{|c|c|c|c|c|c|c|c|}
\hline DV: performance & M1 & M2 & M3 & M4 & M5 & M6 & M7 \\
\hline \multicolumn{8}{|l|}{ Control variables } \\
\hline Economic growth & $0.13^{+}$ & $0.13^{\dagger}$ & 0.11 & 0.12 & $0.15^{*}$ & $0.13^{+}$ & 0.12 \\
\hline Government regulation & $0.13^{\dagger}$ & $0.15^{+}$ & $0.13^{\dagger}$ & $0.13^{\dagger}$ & $0.13^{\dagger}$ & $0.18^{*}$ & $0.13^{+}$ \\
\hline Entry barrier & $0.21^{\star *}$ & $0.19^{* *}$ & $0.20^{* *}$ & $0.17^{\star}$ & $0.19^{* *}$ & $0.17^{*}$ & $0.19 *$ \\
\hline Competitive intensity & -0.04 & -0.02 & -0.01 & -0.04 & -0.02 & -0.01 & 0.00 \\
\hline Firm size & 0.00 & -0.04 & -0.02 & -0.01 & -0.04 & -0.03 & -0.02 \\
\hline Innovation orientation & $0.19 * *$ & $0.15^{\dagger}$ & $0.15^{+}$ & $0.15^{\dagger}$ & $0.15^{+}$ & $0.15^{+}$ & $0.17^{\dagger}$ \\
\hline \multicolumn{8}{|l|}{ Environmental factors } \\
\hline OECD membership (OECD) & 0.00 & -0.01 & 0.00 & 0.01 & -0.03 & -0.01 & 0.02 \\
\hline Local business condition (LB) & $-0.14^{\dagger}$ & -0.13 & -0.11 & $-0.16^{+}$ & -0.13 & $-0.18^{*}$ & $-0.15^{\dagger}$ \\
\hline Resource availability (RA) & -0.01 & 0.01 & -0.01 & 0.00 & 0.05 & 0.03 & 0.00 \\
\hline Investor availability (IA) & 0.07 & 0.06 & 0.06 & 0.06 & 0.05 & 0.06 & 0.08 \\
\hline Customer demandingness (CD) & -0.04 & -0.06 & -0.10 & -0.04 & -0.08 & -0.05 & -0.06 \\
\hline \multicolumn{8}{|l|}{ Market orientation dimensions } \\
\hline Customer orientation (CUS) & & $0.17^{*}$ & $0.15^{*}$ & $0.16^{*}$ & $0.14^{+}$ & $0.17^{*}$ & $0.15^{*}$ \\
\hline Competitor orientation (COM) & & 0.05 & 0.13 & 0.02 & 0.05 & 0.04 & 0.03 \\
\hline Interfunctional coordination & & -0.13 & -0.12 & -0.09 & -0.12 & -0.11 & -0.11 \\
\hline \multicolumn{8}{|l|}{ Hypothesized effects } \\
\hline H1: CUS $\times$ OECD & & & $0.29 * *$ & & & & \\
\hline $\mathrm{COM} \times \mathrm{OECD}$ & & & $-0.29^{* *}$ & & & & \\
\hline H2: CUS × LB & & & & $0.19^{* *}$ & & & \\
\hline $\mathrm{COM} \times \mathrm{LB}$ & & & & $-0.12^{\dagger}$ & & & \\
\hline H3: CUS $\times$ RA & & & & & $0.12^{\dagger}$ & & \\
\hline $\mathrm{COM} \times \mathrm{RA}$ & & & & & $-0.17^{\star}$ & & \\
\hline CUS $\times$ IA & & & & & & $0.15^{*}$ & \\
\hline $\mathrm{COM} \times \mathrm{IA}$ & & & & & & $-0.28^{* *}$ & \\
\hline $\begin{array}{l}\text { H4: } \mathrm{CUS} \times \mathrm{CD} \\
\mathrm{COM} \times \mathrm{CD}\end{array}$ & & & & & & & $\begin{aligned} 0.16^{*} \\
-0.05\end{aligned}$ \\
\hline$R^{2}$ & 016 & & & בר 0 & רי 0 & 0 & ו 0 \\
\hline Adjusted $R^{2}$ & 0.11 & 0.19 & $\begin{array}{l}0.25 \\
0.18\end{array}$ & 0.23 & 0.22 & 0.23 & 0.14 \\
\hline$\Delta R^{2}$ & & $0.03^{*}$ & $0.06^{* *}$ & $0.04^{*}$ & $0.03^{*}$ & $0.06^{* *}$ & $0.02^{+}$ \\
\hline
\end{tabular}

**P $<0.01, * \mathrm{P}<0.05,{ }^{\dagger} \mathrm{P}<0.10$ (two-tailed). 
Table 4. Standardized estimates: subgroup analyses.

\begin{tabular}{|c|c|c|c|c|c|c|}
\hline & \multicolumn{2}{|c|}{ Customer orientation } & \multirow[t]{2}{*}{ Coefficient difference t-test } & \multicolumn{2}{|c|}{ Competitor orientation } & \multirow[t]{2}{*}{ Coefficient difference t-test } \\
\hline OECD membership & $\begin{array}{l}O E C D \\
0.38^{* *}\end{array}$ & $\begin{array}{c}\text { Non-OECD } \\
-0.02\end{array}$ & & $\begin{array}{l}O E C D \\
-0.15\end{array}$ & $\begin{array}{c}\text { Non-OECD } \\
0.23^{*}\end{array}$ & \\
\hline Local business conditions & $\begin{array}{l}\text { Good } \\
0.33^{* *}\end{array}$ & $\begin{array}{l}\text { Poor } \\
0.00\end{array}$ & $2.06^{*}$ & $\begin{array}{l}\text { Good } \\
-0.03\end{array}$ & $\begin{array}{l}\text { Poor } \\
0.17^{*}\end{array}$ & $1.71^{\dagger}$ \\
\hline Resource availability & $\begin{array}{l}\text { High } \\
0.27^{\star}\end{array}$ & $\begin{array}{l}\text { Low } \\
0.04\end{array}$ & $1.87^{\dagger}$ & $\begin{array}{r}\text { High } \\
-0.08\end{array}$ & $\begin{array}{l}\text { Low } \\
0.18^{+}\end{array}$ & $1.79^{\dagger}$ \\
\hline Investor availability & $\begin{array}{l}\text { High } \\
0.37^{* *}\end{array}$ & $\begin{array}{l}\text { Low } \\
-0.11\end{array}$ & $2.85^{* *}$ & $\begin{array}{c}\text { High } \\
-0.22^{*}\end{array}$ & $\begin{array}{l}\text { Low } \\
0.37^{* *}\end{array}$ & $3.65^{* *}$ \\
\hline Customer demandingness & $\begin{array}{l}\text { High } \\
0.29^{* *}\end{array}$ & $\begin{array}{l}\text { Low } \\
-0.06\end{array}$ & $2.05^{*}$ & $\begin{array}{l}\text { High } \\
0.04\end{array}$ & $\begin{array}{l}\text { Low } \\
0.06\end{array}$ & 0.19 \\
\hline
\end{tabular}

**P $<0.01, * \mathrm{P}<0.05,{ }^{\dagger} \mathrm{P}<0.10$ (two-tailed). 


\section{APPENDIX}

The measurement items and results of the validity analyses are given Table A1.

Table A1 Measurement items and validity assessment

Overall model fit: $x^{2}(290)=419.83, P<0.001 ; C F I=0.93, T L I=0.91 ; R M S E A=0.049$

SFL

Customer orientation: $\mathrm{CR}=0.846, \mathrm{AVE}=0.504, \mathrm{HSV}=0.222$

1. The top management of our hotel often emphasizes the need to be customer oriented. $\quad 0.570$

2. We reward employees and managers who are committed to customer satisfaction. $\quad 0.538$

$\begin{array}{ll}\text { 3. We regularly measure customer satisfaction. } & 0.692\end{array}$

4. We spend a great deal of effort trying to understand customer needs. 0.824

5. We do whatever it takes to create value for our customers. $\quad 0.720$

$\begin{array}{ll}\text { 6. We continuously monitor our customers’ needs. } & 0.782\end{array}$

Competitor orientation: CR¹/40.700, AVE¹/40.464, HSV1/40.295

1. Our sales and marketing people share competitor information with other departments. $\quad 0.516$

2. We respond rapidly to our competitors’ actions. $\quad 0.809$

3. We are constantly looking for opportunities to gain an advantage over our competitors. $\quad 0.644$

Interfunctional coordination: $\mathrm{CR}=0.783, \mathrm{AVE}=0.553, \mathrm{HSV}=0.295$

1. The various departments in our hotel share a great deal of information with each other. 0.801

2. Our hotel's strategy emphasizes coordination of the various departments. $\quad 0.837$

3. Resources are frequently shared by different departments. $\quad 0.564$

4. Tightly coordinating the activities of all departments adds customer value. $a$

Organizational performance: $\mathrm{CR}=0.756, \mathrm{AVE}=0.514, \mathrm{HSV}=0.084$ 
Compared to your direct competitors, how well did your hotel do in the following measures?

$\begin{array}{ll}\text { 1. Occupancy } & 0.757\end{array}$

2. Gross operating profit 0.553

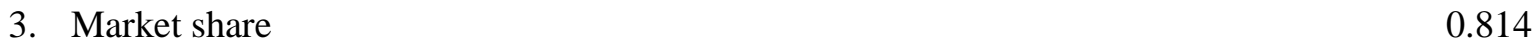

Customer demandingness (1: strongly disagree; 5: strongly agree): $\mathrm{CR}=0.727, \mathrm{AVE}=0.505, \mathrm{HSV}=0.192$

1. Our customers belong to a very exclusive class whose needs are unique. 0.592

2. Our customers are very particular about the service they receive. $\quad 0.881$

3. We would not succeed in this market without providing excellent service. $\quad 0.564$

Please provide your assessment of the business environments facing your hotel by circling the number that best represents your assessment.

Local business conditions (1: very poor; 5: very good): $\mathrm{CR}=0.827, \mathrm{AVE}=0.615, \mathrm{HSV}=0.251$

1. Quality of infrastructure (phones, roads, etc.) $\quad 0.834$

$\begin{array}{lr}\text { 2. General business conditions } & 0.800\end{array}$

$\begin{array}{lr}\text { 3. Political stability } & 0.715\end{array}$

Resource availability (1: very low; 5: very high): CR¹/40.841, AVE1/40.642, HSV1/40.251

$\begin{array}{ll}\text { 1. Qualified service employees } & 0.802\end{array}$

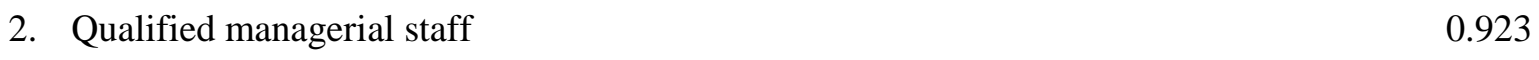

$\begin{array}{lr}\text { 3. Reliable suppliers } & 0.656\end{array}$

Investor availability (1: very low; 5: very high): CR¹/40.809, AVE¹/40.682, HSV1/40.187

$\begin{array}{ll}\text { 1. Qualified local investment partners } & 0.717\end{array}$

2. Trustworthy local investment partners $\quad 0.922$ 
Market (0=non-OECD markets; $1=$ OECD markets)

${ }^{a}$ Item deleted from further analysis due to low factor loading.

Notes: SFL=standardized factor loading; $\mathrm{CR}=$ composite reliability; $\mathrm{AVE}=$ average variance extracted;

HSV=highest shared variance with other 